УДК 631.316.022, DOI 10.31210/visnyk2018.02.27

2018

Ляшенко С. В., кандидат технічних наук

Полтавська державна аграрна академія

\title{
УДОСКОНАЛЕННЯ МЕХАНІЗОВАНОЇ ТЕХНОЛОГІЇ ВИРОЩУВАННЯ КАРТОПЛІ НА ПРИСАДИБНИХ ДІЛЯНКАХ
}

\section{Рецензент - кандидат технічних наук В. В. Падалка}

\begin{abstract}
Розглянуто механізовану технологію вирощування картоплі в умовах особистого селянського господарства. Проведено аналіз та систематизацію марок (моделей) засобів малої механізаиії для виконання відповідних операцій технологічного процесу вирощування картоплі. Обгрунтовано дочільність використання лемішно-стрілчастого підгортача в якості робочого органу, щзо поєднує дві механізовані операції технологічного процесу - прополювання та пригортання. Наведено аналіз конструкиій начіпного обладнання засобів малої механізації. Встановлено, щзо для зниження трудовитрат у технології міжрядкового обробітку насаджень картоплі та з метою підвищеени урожайності слід використовувати в якості начіпного обладнання лемішно-стрілчастий підгортач.
\end{abstract}

Ключові слова: технологія, механізована операчія, вирощування, картопля, засоби малої механізації, начіпне обладнання, лемішнострілчастий підгортач, технологія міжрядного обробітку.

Постановка проблеми. Картоплярство $є$ однією $з$ провідних галузей у сільськогосподарському виробництві, адже недарма в народі картоплю називають другим хлібом. Науково обгрунтована норма споживання картоплі однією людиною в рік - 135 кг, а реальне споживання населенням України становить 116-130 кг [3]. Картоплярство - традиційна галузь сільськогосподарського виробництва Полтавщини. Питома вага області у виробництві і реалізації картоплі в Україні становить 20-25\%.

Особисті підсобні господарства значно краще використовують надані їм землі. Сучасні господарства громадян стали основними виробниками картоплі, овочів та іншої продукції. Водночас технологічний процес вирощування картоплі на присадибних ділянках потребує значних трудовитрат. Ручна праця становить до $75 \%$ під час вирощування. Тому останнім часом набувають популярності засоби малої механізації $з$ переліком необхідного начіпного обладнання. Проте залишаються не вирішеними питання щодо ефективного його використання на присадибних ділянках та щодо визначення раціональних па- раметрів машин у технологічному процесі вирощування картоплі на присадибних ділянках.

Аналіз останніх досліджень та публікацій, у яких започатковано розв'язання проблеми. Технологія вирощування картоплі включає в себе багато елементів, кожному 3 яких потрібно приділяти особливу увагу. В технології вирощування картоплі слід виділити два основні методи

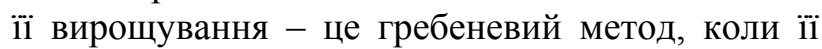
підгортають, та вирощування картоплі без гребенів.

Аналізу технологій вирощування картоплі присвячено роботи Сокальського С. В., Бацанова Н. С., Замотаева А. И. та інших $[5,1,2]$. Узагальнюючи результати досліджень вчених, слід відмітити, що технології вирощування картоплі на присадибних ділянках описані досить повно, але конструкції начіпного обладнання для засобів малої механізації постійно вдосконалюються.

Мета досліджень: підвищення ефективності механізованої технології вирощування картоплі за рахунок зниження енерговитрат шляхом обгрунтування раціональних параметрів і режимів роботи лемішно-стрілчатого пригортача рядків картоплі. Для досягнення мети необхідно провести аналіз існуючих конструкцій пригортачів рядків картоплі.

Завдання досліджень: виявити раціональні конструктивні елементи начіпних робочих органів та адаптувати їх у конструкції дослідного зразка лемішно-стрілчатого пригортача 3 метою підвищення урожайності та зниження трудовитрат у механізованій технології вирощування картоплі на присадибних ділянках.

Результати дослідження. Традиційна механізована технологія вирощування картоплі передбачає дві основні операції по догляду за насадженнями: обробіток грунту в міжряддях (прополювання) та пригортання рядків картоплі [4].

Для обробітку грунту в міжряддях використовують малогабаритні просапні культиватори, які комплектуються різними типами робочих органів: універсальними стрілчатими лапами, лапами-бритвами (право-орієнтованими i лівоорієнтованими), лапами-долотами (рис. 1). 


\section{TEХНIЧНI НАУКИ}

Глибина обробітку регулюється перестановкою лап по висоті в кронштейнах рами, а ширина - переміщенням крайніх лап по балці рами.

Для пригортання рядків картоплі в традиційній механізованій технології вирощування картоплі на присадибних ділянках використовується лемішний підгортач (рис. 2).

Недоліком традиційної механізованої технології вирощування картоплі слід вважати вдвічі збільшені трудовитрати механізованих операцій, оскільки за сезон потрібно, як мінімум, виконати чотири міжрядкових прополювання та стільки ж пригортань рядків картоплі.

У результаті проведеного аналізу конструкцій начіпного обладнання встановлено доцільність використання лемішно-стрілчастого підгортача в якості робочого органу, що поєднує дві механізовані операції технологічного процесу - прополювання та пригортання рядків картоплі (рис. 3 a, б).

3 метою встановлення ефективності використання лемішно-стрілчастого пригортача дослідним шляхом необхідно встановити тяговий опір робочого органу для рядкового пригортання картоплі.

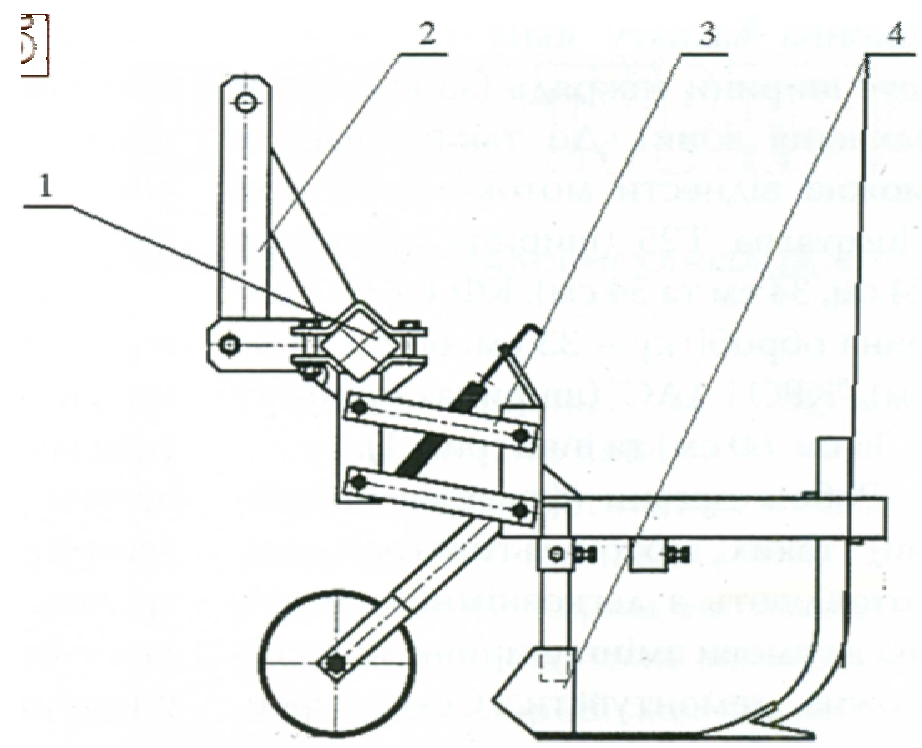

Рис. 1. Начіпне обладнання для міжрядкового обробітку.

1 -брус; 2 - начіпний пристрій; 3 -регулювальний пристрій;

4 - прополювальні леза-бритви та розпущувальна культиваторна лапа

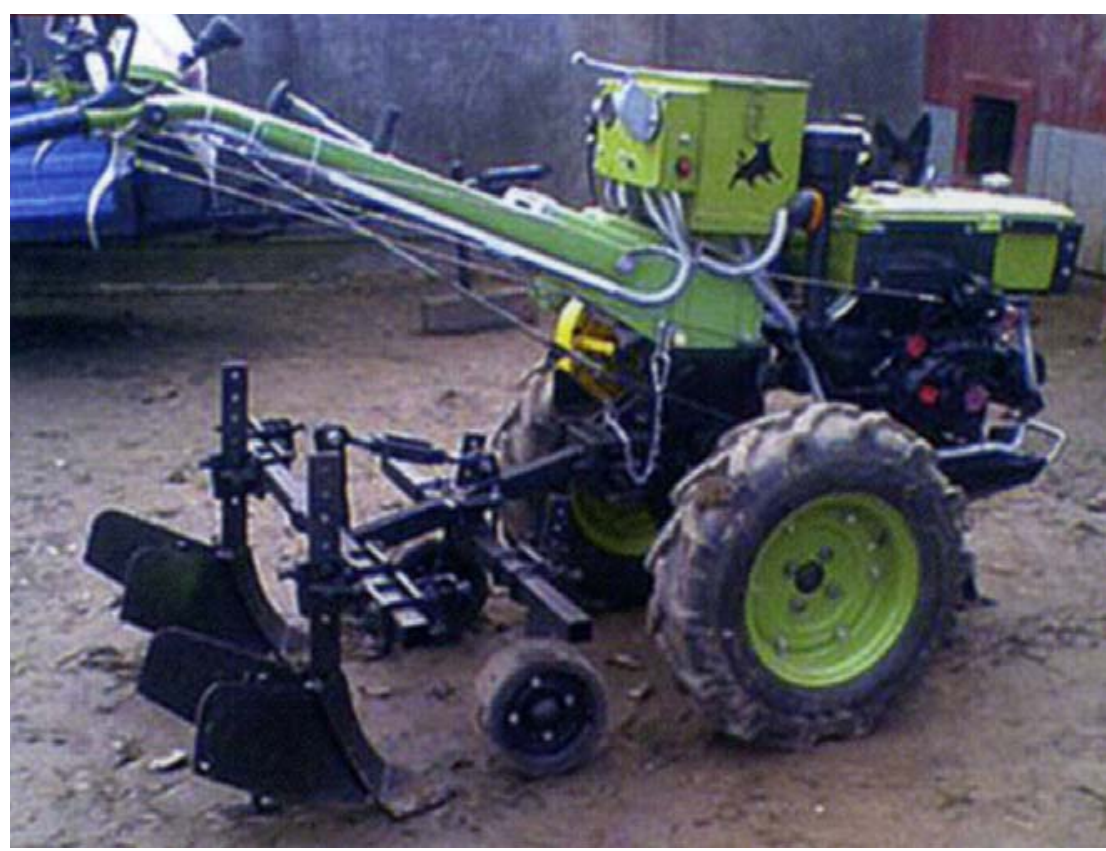

Рис. 2. Мотоблок із лемішним підгортачем 


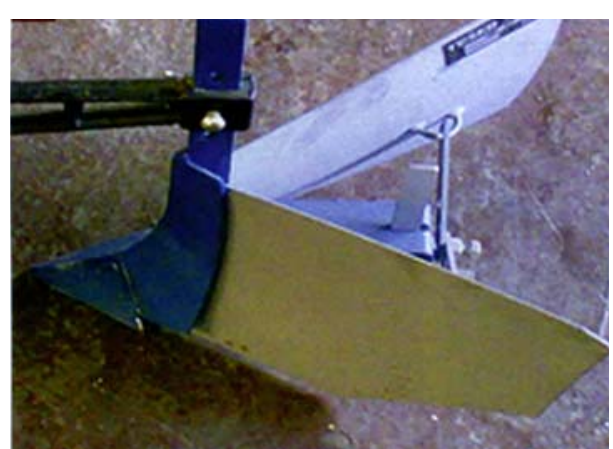

a)

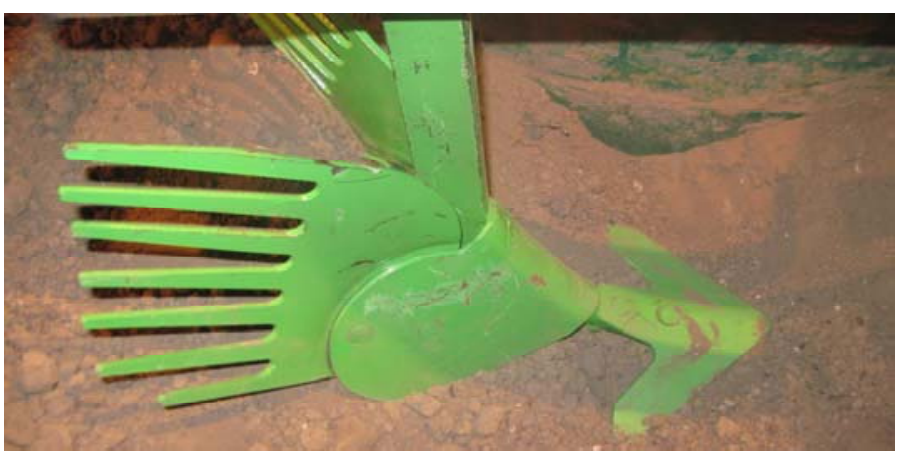

б)

а) лемішний пригортач; б) лемішно-стрілчастий пригортач

\section{Рис. 3. Досліджувані робочі органи}

Середній тяговий опір запропонованого робочого органу слід визначати за формулою $P=-198,59+315,29 \mathrm{~V}+2793,91 \mathrm{H}+147,33 \mathrm{~V}^{2}+154,75 \mathrm{~V} \cdot \mathrm{H}+11200,00 \mathrm{H}^{2}$,

де $V$ - швидкість руху, м/с;

$H$ - глибина обробітку, м.

Для умов грунтового середовища 3 вологістю грунту в межах $W=15 \ldots 22 \%$, твердістю грунту $p=3,89 \ldots 7,57$ МПа рекомендовано використовувати наступні налаштування технологічних параметрів лемішно-стрілчастого пригортача:

Швидкість виконання технологічної операції пригортання картоплі повинна становити 0,091-0,637 м/с, глибина обробітку $-0,01-0,06$ м.

У результаті отримаємо зменшення тягового опору грунту в межах 18 \% у порівнянні 3 лемішним пригортачем (рис. 3 a).

\section{Висновки:}

1. У статті наведено узагальнення і нове вирішення науково-практичного завдання, що виявляється в удосконаленні технології вирощування картоплі на присадибних ділянках шляхом розробки механізованих операцій із застосуванням енергозасобів тягового класу 0,1 . Це дало змогу підвищити продуктивність вирощування сільськогосподарської культури та зменшити затрати ручної праці за рахунок обгрунтування й вибору технічного забезпечення технологічних процесів.

2. У результаті обробки експериментальних даних були отримані рівняння регресії для середнього тягового опору лемішно-стрілчастого пригортача:

$$
P=-198,59+315,29 \mathrm{~V}+2793,91 \mathrm{H}+147,33 \mathrm{~V}^{2}+154,75 \mathrm{~V} \cdot \mathrm{H}+11200,00 \mathrm{H}^{2}
$$

3. Оптимальними значеннями параметрів для умов експерименту та застосованої конструкції лемішно-стрілчастого пригортача $€$ швидкість руху в межах 0,091-0,637 м/с та глибина обробітку 0,010,06 м. За вищевказаних параметрів тяговий опір становив $120-400 \mathrm{H}$.

4. Для особистих присадибних ділянок у механізованій технології вирощування картоплі слід використовувати лемішно-стрілчастий пригортач, який у своїй конструкції поєднував би переваги промислових машин за доступну вартість.

\section{БІБЛІОГРАФІЯ}

1. Бацанов Н. С. Картофель. - М.: Колос, 1970. $-283 \mathrm{c}$.

2. Замотаев А. И., Лубенцова В. М., Золовик $A$. $C$. Интенсивная технология производства картофеля. - М. : Росагропромиздат, 1989. - 19 с.

3. Картопля / Сост. Т. Е. Лущіц. - Мн. : Книжковий дім, 2001. -80 с. : Ил.

4. Картофелеводство : научные труды / БелНИИ картофелеводства. - Минск : Мерлит, 2002. - 38 с.
5. Сокальський С. В. Сучасний стан та перспективи розвитку галузі картоплярства // Формування стратегії розвитку регіонального АПК : матеріали четвертої міжфак. наук.-практ. конф. молодих вчених, 30 травня, 2008 р. - М-во аграр. політики України, ДВНЗ «Державний агроекологічний університет». - Житомир : вид-во ДВНЗ «ДАУ», 2008. - С. 102-105. 


\section{ANNOTATION}

Liashenko S. V. Improvement of mechanized technology of potato growing at the private sites.

The article provides justification and a new solution of the scientific and practical task, which takes place in the improvement of the mechanized technology of growing potatoes on the personal plots of ways of developing a mechanized operation with the use of means of minor mechanization of the traction class 0.1 . The mechanized technology of growing potatoes under conditions of peasant farming is considered. The analysis and systematization of brands (models) of small-scale mechanization means for performing the corresponding operations of the technological process of growing potatoes is carried out. Defects of existing structures are determined and a new constructive solution is offered. The expediency of using the lem-and-lance hiller as a working organ that combines two mechanized operations of the technological process-weeding and humming is justified. It makes it possible to reduce the number of technological passes of the unit, to reduce labor productivity, to save fuel consumption, which in turn will increase the yield by $18 \%$. The analysis of constructions of the hinged equipment of means of small mechanization is given. The following effective parameters of the unit operation are recommended: the speed of movement is in the range of $0.091-0.637 \mathrm{~m} / \mathrm{s}$, the processing depth is 0.01-0.06 m. Under these conditions, the traction resistance will be $120-400 \mathrm{~N}$.

It has been established that to reduce labor costs in the technology of inter-row cultivation of plantations of potatoes and for the purpose of increasing the yield, it is necessary to use a lem-andlancet hiller as a hinged equipment. It is recommended to use a lemically-stellate hiller for rural regions in the mechanized technology of growing potatoes.

Key words: technology, mechanized operation, cultivation, potatoes, small-scale mechanization means, attachments, lemmish-lancet hillslayer, inter-row cultivation technology. 